\title{
ASPECTS OF YOUTH COMPETENCIES IN THE 21ST CENTURY IN THE EUROPEAN UNION
}

\author{
Loredana Pribac \\ pribacloredana@gmail.com \\ Dorina Ardelean \\ dorina_ardelean@yahoo.com \\ Lavinia Dudas \\ laviniamustea@gmail.com \\ Cristian Haiduc \\ c_haiduc@uvvg.ro \\ Andrei Anghelina \\ a_anghelina@uvvg.ro \\ „Vasile Goldiş” Western University of Arad
}

(Received, June 2017; Accepted, November 2017)

\begin{abstract}
The aim of this article is to present the youth unemployment problem that the European Union countries are facing nowadays. To this end, we investigate the competencies and skills considered necessary in the 21 Century. We do this by presenting the competencies considered important by European employers versus Romanian employers. Not least, we reveal future directions in terms of skills required by employers.
\end{abstract}

Key words: youth unemployment, 21 Century competencies, required skills

J.E.L. CODES: E24, F6

\section{Introduction}

Over the past 30 years, major changes have taken place in countries around the world in the political, economic and social spheres. Moreover, the technology has exploded, has developed rapidly, expanded worldwide and nowadays it plays an important role in all fields.

At the same time, we should ask ourselves what has happened to people in the last 30 years. The people who grew up with these changes are integrated into this "new society," and the others who lived in another era, some have adapted, while others are still behind. The question is: What does society do for the latter? And have all the young people really been integrated in the scroll of our day?

The recent financial crisis has destabilized the global economies and its effects are still felt in some sectors of activity. A major effect of the crisis was the increase in the number of unemployed in all areas of activity, but especially in the case of young people without experience. Thus, a major problem for our society is the number of the unemployed, which in some countries is at a low level, and in others

12 Studia Universitatis "Vasile Goldis" Arad. Economics Series Vol 27 Issue 4/2017

ISSN: 1584-2339; (online) ISSN: 2285 - 3065

Web: publicatii.uvvg.ro/index.php/studiaeconomia.Pages $12-25$ 
it is high. These unemployed also refer to young unemployed people, who according to Figure 1.1 are at a worrying level. What are the causes of youth unemployment, which seems to exist in several European countries, but especially how we can combat this, is the theme of this article. Are employers or employees guilty of this? Who is the problem and how can it be solved?

As depicted in Figure 1.1, we can affirm that the Romanian youth unemployment rate is lower than in Spain or Greece.

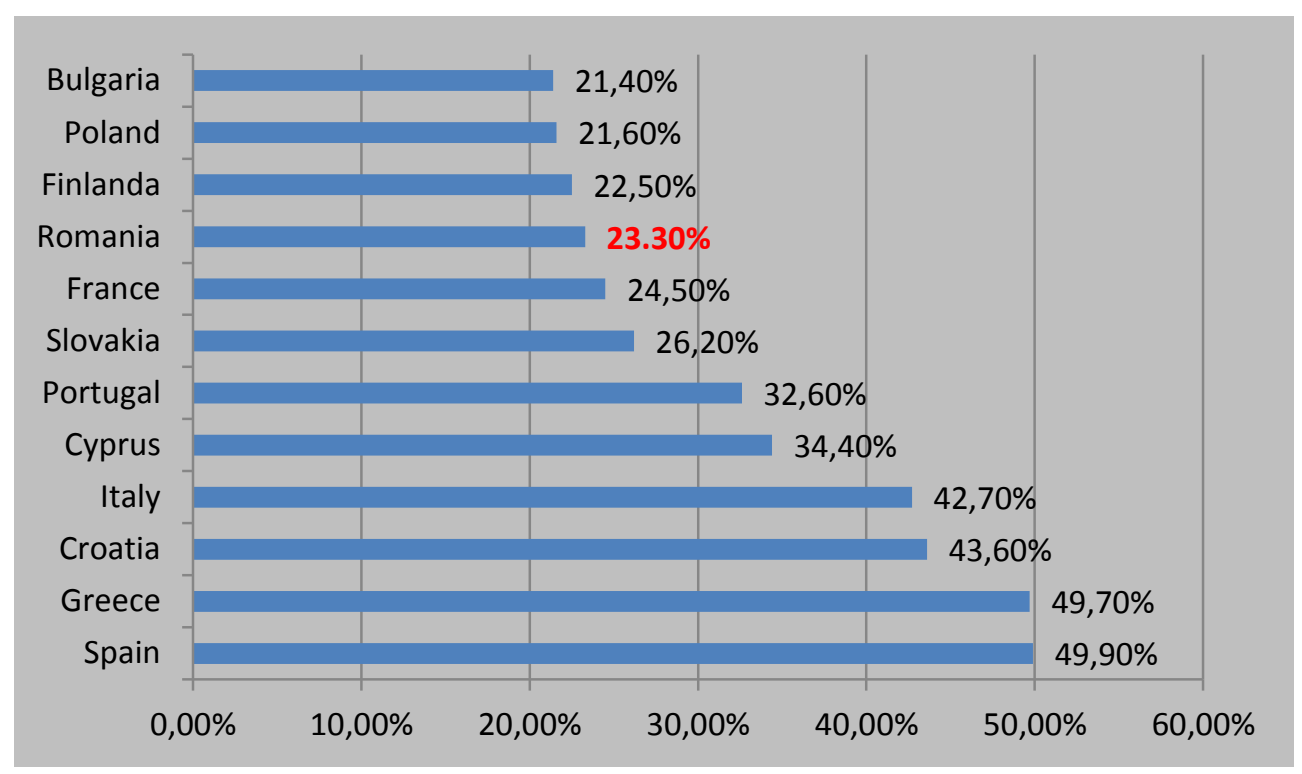

Figure 1.1 Youth unemployment in 21 Century

Source: Eurostat

The rest of the paper is organized as follows. The first part presents theoretical aspect regarding competencies and skills, while the second part analyses the competencies required by employers in the European Union and Romania. The third part reveals some future directions in terms of skills required by employers and the fourth part concludes.

\section{Theoretical aspects regarding competencies and skills}

According to Smartree the skills required for the 21st Century people can be divided into three main groups (Figure 1.2):

a) Fundamental (study areas during school years)

b) Skills that are acquired during school years but which relate to communication 
Pribac L., Ardelean D., Dudaș L., Haiduc C., Anghelina A. (2017)

Aspects of youth competencies in the 21st century in the European Union

c) The qualities of each person's character (which makes us unique) - social skills.

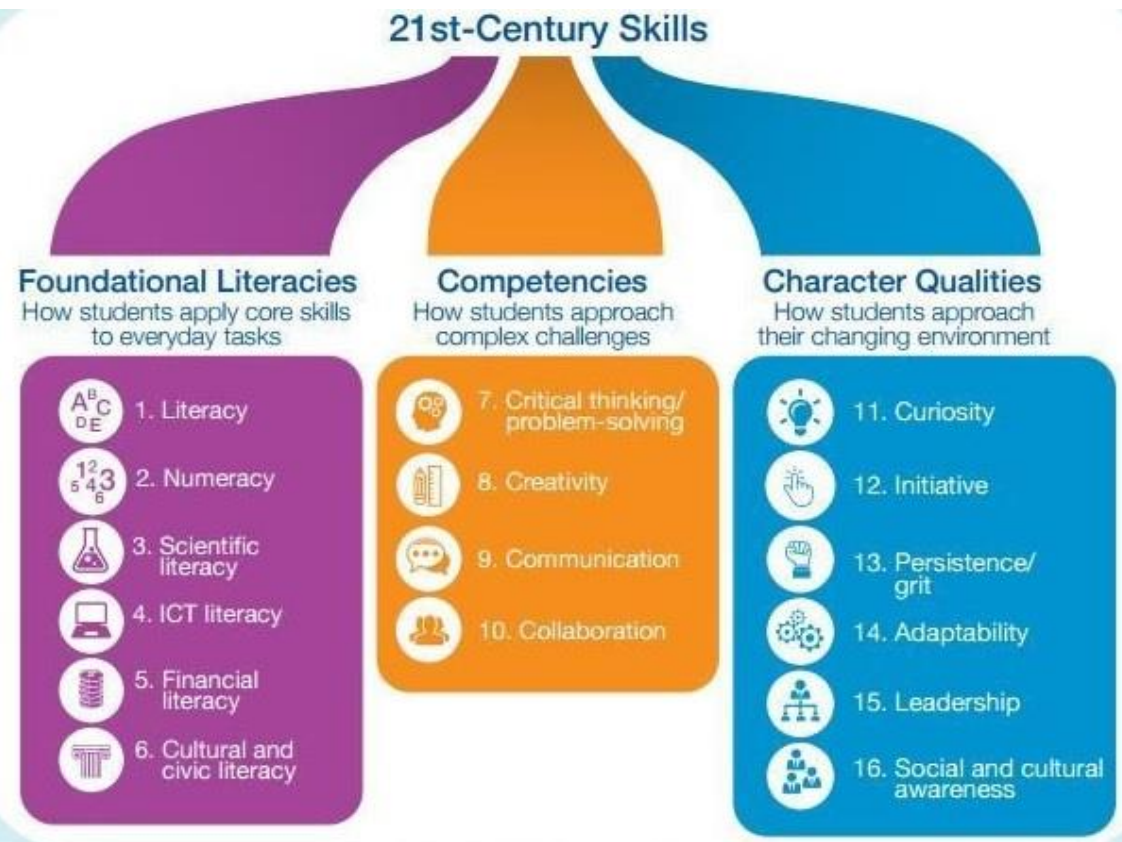

Figure 1.2 Competencies

Source: www.smartree.com

Another recent way to see the skills required nowadays is revealed in Table 1.1, namely by taking into consideration the professional - personal dimension and the conceptual - operational dimension.

Table 1.1 Skills types of the 21th Century

\begin{tabular}{|l|l|l|}
\hline & \multicolumn{1}{|c|}{ Professional } & \multicolumn{1}{c|}{ Personal } \\
\hline Conceptual & $\begin{array}{l}\text { Cognitive skills } \\
\text { (knowledge) }\end{array}$ & $\begin{array}{l}\text { Meta-competence } \\
\text { (Facilitating learning) }\end{array}$ \\
\hline Operational & $\begin{array}{l}\text { Functional competence } \\
\text { (Skills) }\end{array}$ & $\begin{array}{l}\text { Social competence } \\
\text { (Attitudes and behaviors) }\end{array}$ \\
\hline
\end{tabular}

Source: www.red-seal.ca

An important factor that influences the competencies and skills acquired by youth people is the structure and quality of educational standards in each country. It can 
Pribac L., Ardelean D., Dudaș L., Haiduc C., Anghelina A. (2017)

Aspects of youth competencies in the 21st century in the European Union

easily be observed in Table 1.2 that only Romania, Belgium, Slovenia and Spain have all the criteria that are part of the EU education system. Is this a good thing for these countries or not?

Table no. 1.2

Structure and quality of educational standards in the European Union countries

\begin{tabular}{|c|c|c|c|c|c|c|}
\hline \multirow[b]{2}{*}{ EU Countries } & \multicolumn{2}{|c|}{ Occupational Standards } & \multicolumn{4}{|c|}{ Education and assessment related standards } \\
\hline & $\begin{array}{c}\text { Tasks, } \\
\text { activities } \\
\text { functions }\end{array}$ & Competences & $\begin{array}{l}\text { Learning } \\
\text { Outcomes }\end{array}$ & $\begin{array}{c}\text { Assessment } \\
\text { criteria and } \\
\text { methods }\end{array}$ & $\begin{array}{c}\text { Subject-based } \\
\text { framework } \\
\text { curriculum } \\
\end{array}$ & Syllabus \\
\hline Austria & $\bullet$ & $\bullet$ & $\bullet$ & $\bullet$ & $\bullet$ & \\
\hline Belgium & $\bullet$ & $\bullet$ & $\bullet$ & $\bullet$ & $\bullet$ & $\bullet$ \\
\hline Bulgaria & $\bullet$ & $\bullet$ & $\bullet$ & $\bullet$ & $\bullet$ & \\
\hline Czech Republic & & & $\bullet$ & & $\bullet$ & \\
\hline Denmark & & & $\bullet$ & $\bullet$ & $\bullet$ & \\
\hline Estonia & - & $\bullet$ & & & - & \\
\hline Finland & & & $\bullet$ & $\bullet$ & • & \\
\hline France & $\bullet$ & $\bullet$ & $\bullet$ & $\bullet$ & & \\
\hline Germany & & & $\bullet$ & $\bullet$ & $\bullet$ & \\
\hline Greece & $\bullet$ & $\bullet$ & & & $\bullet$ & $\bullet$ \\
\hline Hungary & $\bullet$ & $\bullet$ & $\bullet$ & $\bullet$ & $\bullet$ & \\
\hline Ireland & & & $\bullet$ & $\bullet$ & & \\
\hline Italy & $\bullet$ & & $\bullet$ & $\bullet$ & $\bullet$ & $\bullet$ \\
\hline Latvia & $\bullet$ & $\bullet$ & 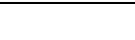 & $\bullet$ & $\bullet$ & \\
\hline Lithuania & $\bullet$ & $\bullet$ & - & & & \\
\hline Luxemburg & & - & - & - & $\bullet$ & - \\
\hline Malta & & $\bullet$ & $\bullet$ & $\bullet$ & & \\
\hline Netherlands & & & $\bullet$ & $\bullet$ & & \\
\hline Poland & & & - & - & • & - \\
\hline Portugal & $\bullet$ & $\bullet$ & $\bullet$ & $\bullet$ & & \\
\hline Romania & $\bullet$ & $\bullet$ & $\bullet$ & $\bullet$ & $\bullet$ & $\bullet$ \\
\hline Slovenia & $\bullet$ & $\bullet$ & $\bullet$ & $\bullet$ & $\bullet$ & $\bullet$ \\
\hline Spain & $\bullet$ & $\bullet$ & $\bullet$ & $\bullet$ & $\bullet$ & $\bullet$ \\
\hline United Kingdom & $\bullet$ & $\bullet$ & & $\bullet$ & & \\
\hline Switzerland & & $\bullet$ & $\bullet$ & $\bullet$ & & \\
\hline Norway & & & $\bullet$ & $\bullet$ & $\bullet$ & $\bullet$ \\
\hline Sweden & & & $\bullet$ & $\bullet$ & $\bullet$ & • \\
\hline
\end{tabular}

Source: www.red-seal.ca

Possible consequences of the fact that young people acquire more skills and young people have a certain level of education are:

- several young people finish school;

- low crime rate among young people;

DE GRUYTER OPEN
Studia Universitatis "Vasile Goldis" Arad. Economics Series Vol 27 Issue 4/2017 ISSN: 1584-2339; (online) ISSN: 2285 - 3065 
- less drug abuse among young people;

- more young people who work voluntarily;

- more young people participating in the elections.

(Quality Youth Work - European Commission, 2015)

Examples of qualitative effects on young people which have a certain level of education include:

- Perceived experiences/ feelings (e.g. better self-esteem)

- Changed attitudes (e.g. to immigrants)

- Developed soft skills (e.g. ability to cooperate)

- Developed skills (e.g. ability to cook)

- Gained knowledge (e.g. about the European Union).

(Quality Youth Work - European Commission, 2015)

Qualitative effects are what actually happens to young people, how they develop, as a result of their taking part in education. So, a good education/ education about their real needs is very important for young people.

\section{Methodology}

To analyse the theme presented in this article we started from the statistical data provided by Eurostat. Then we analysed some theoretical aspects regarding education (information provided by different institutions).

Starting from the data obtained within the project financed by European funds, SOPHRD, we analysed at the level of Romania and the European Union the competencies required by employers of young people looking for a job.

Then we analysed the data provided by hiring sites. Finally, we presented the future trend regarding the skills that young people have to acquire when finishing the university, because when they go to work, employers are satisfied, and there is no longer a high unemployment rate among young people.

\section{Competencies required by employers in the European Union versus Romania. CVs sent versus vacant jobs in Romania.}

Following a study made by Cedefop Europe (Figure 3.1.), European employers is searching for people who combine the following skills: specific knowledge required for the workplace, communication skills, open to learning, team work and problem resolving skills. 
Pribac L., Ardelean D., Dudaș L., Haiduc C., Anghelina A. (2017)

Aspects of youth competencies in the 21 st century in the European Union

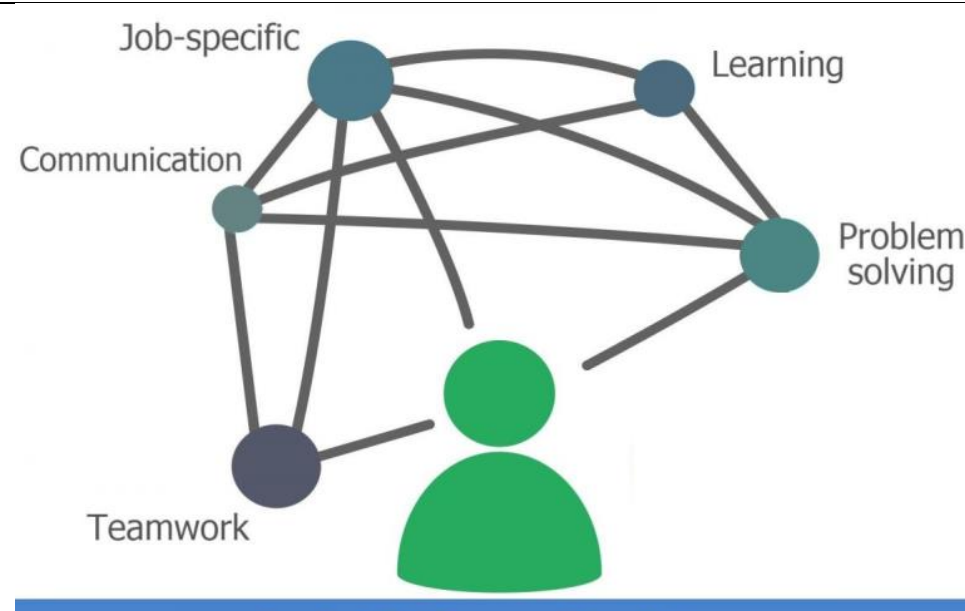

From Cedefop's European skills and jobs survey

Figure 3.1. Competencies required in Europe

Source: www.cedefop.europa.eu

In what concerns Romania, a study realized through a SOPHRD (Figure 3.2) project revealed that the Romanian employers search for 12 competencies when they want to hire a person.

- Experience

- Knowledge of one or more languages

- Teamwork

- Organizing various activities

- Responsibility

- Stress resistance

- Result orientation and ability to solve problems

- Effective action capacity under uncertainty

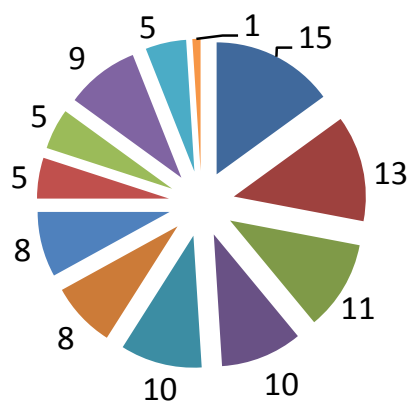

Making decisions based on their own analysis (no influence from outside)

- Initiative

Knowing how to learn permanently

- Other competencies

Figure 3.2 Competencies required in Romanian

Source: Project "O carieră pentru viața ta! Oportunităti de carieră prin orientare și consiliere profesională“- SOPHRD 161/2.1/G/132792

DE GRUYTER OPEN
Studia Universitatis "Vasile Goldis" Arad. Economics Series Vol 27 Issue 4/2017 ISSN: 1584-2339; (online) ISSN: 2285 - 3065 
As presented in the above studies on the required skills by entrepreneurs nowadays, we can see that what is being requested at European level is also requested in Romania. An explanation could be that Romania has begun to comply with international requirements or/and standards, or perhaps the large number of multinationals companies in Romania influenced this. To be more precise, in the multinationals that activates in Romania the standards required are the same as in the company home country, thus, gradually the Romanian employers have started to take on certain requirements regarding the skills of their employees.

Annex reveals at national level, the fields of activity where Romania has vacant jobs in the last period. The domain with the largest job offer is sales, followed by the call center field, and at a great distance are the areas: transportation, translation or production. Therefore, if Romania has unemployed among young people, it is also due to the fact that they do not have the necessary skills to fill these vacancies. Looking from a different perspective, we can see that CVs sent to recruitment sites are as depicted in figure 3.3.: engineering, customer service, accounting, marketing and medical. We can easily conclude that they do not meet the job offer that is nowadays on the market. It can be seen that there is a discrepancy and a lack of synchronization between areas where young people are studying and employers' job offers.

This problem can be solved only at national level through cooperation between state institutions, universities and the business area.

- Marketing

- Management

- Accountancy

IT\&C

Medical / Pharmacy



Figure 3.3 CVs sent to recruitment sites in Romania in 2016 Source: bestjobs, ejobs 
Pribac L., Ardelean D., Dudaș L., Haiduc C., Anghelina A. (2017)

Aspects of youth competencies in the 21 st century in the European Union

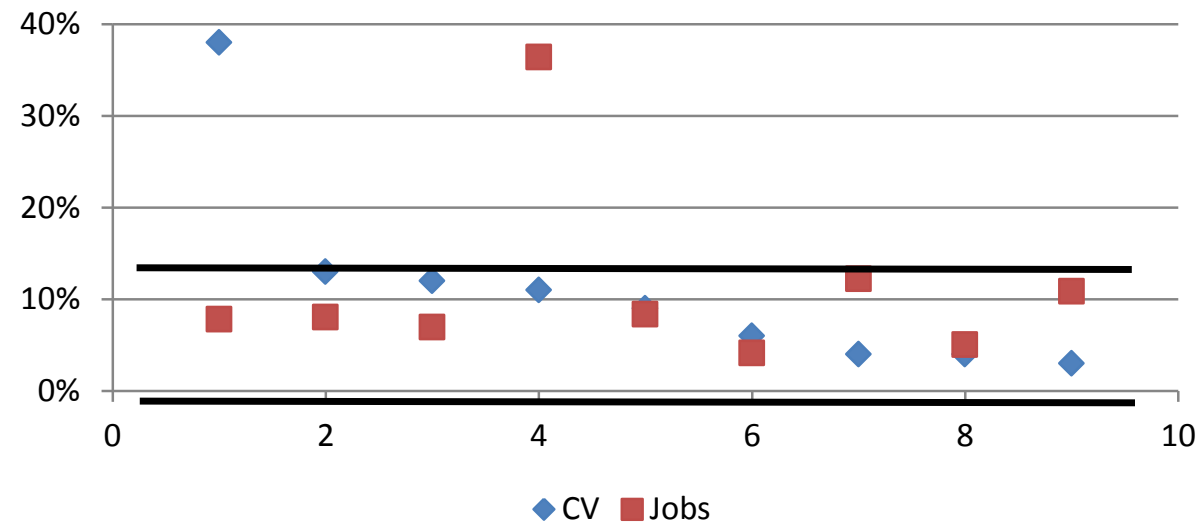

Figure 3.4 The relationship between $\mathrm{CV}$ sent and vacant jobs (I)

Source: own work

From the data provided by specialized websites, the following aspects are emerging: the number of young people who finish an engineering / technology specialization is far too high compared to the demand on the market (vacant jobs), and the opposite is the service field (here included all kinds of services) where the number of young people with a specialization in the field is small. The most balanced areas were Production and Accounting.

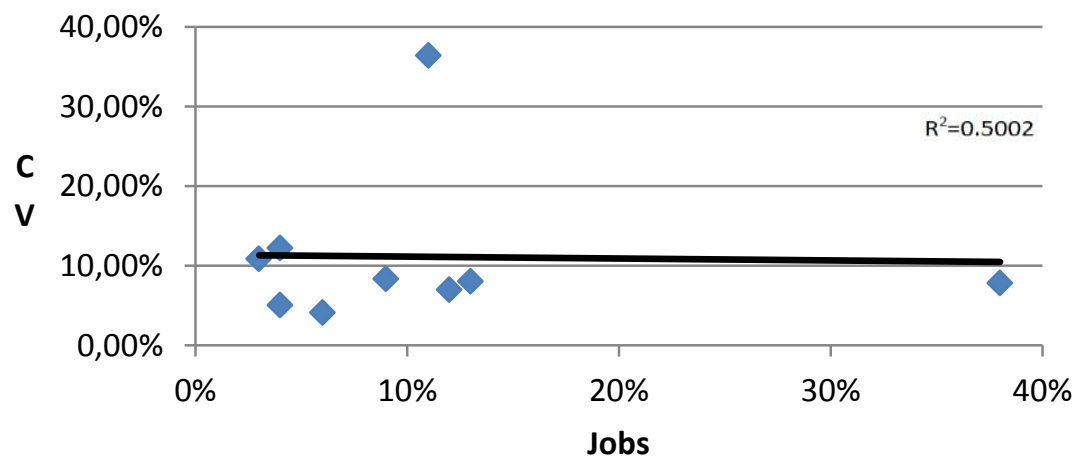

Figure 3.5 The relationship between CV sent and vacant jobs (II) Source: own work

DE GRUYTER OPEN
Studia Universitatis “Vasile Goldis" Arad. Economics Series Vol 27 Issue 4/2017 ISSN: 1584-2339; (online) ISSN: 2285 - 3065 
Pribac L., Ardelean D., Dudas L., Haiduc C., Anghelina A. (2017)

Aspects of youth competencies in the 21 st century in the European Union

Between the two indicators there is a statistical correlation, but unfortunately the demand and job offer on the Romanian market does not fit in most of the analysed domains.

\section{Future directions in terms of skills required by employers}

As depicted by Figure 4.1 we also consider that in the 21st century society, there are 6 directions of change, which can be transposed in the skills considered vital in the future for all people who want to engage in a company.
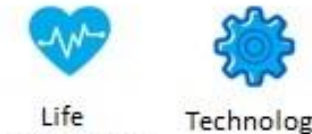

expectancy

Technology
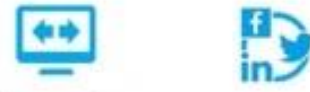

Computer

Media

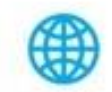

Internet

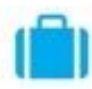

Superstructured organizations

Figure 4.1 Required competencies

In this context, the educational systems need to take into consideration and to adopt rapidly the changes in society, namely to take into consideration the new employers requirements in order to recruit graduates. To be more precise, Figure 4.2 reveals what education institutions should provide to students in order to be able to produce hireable people nowadays.

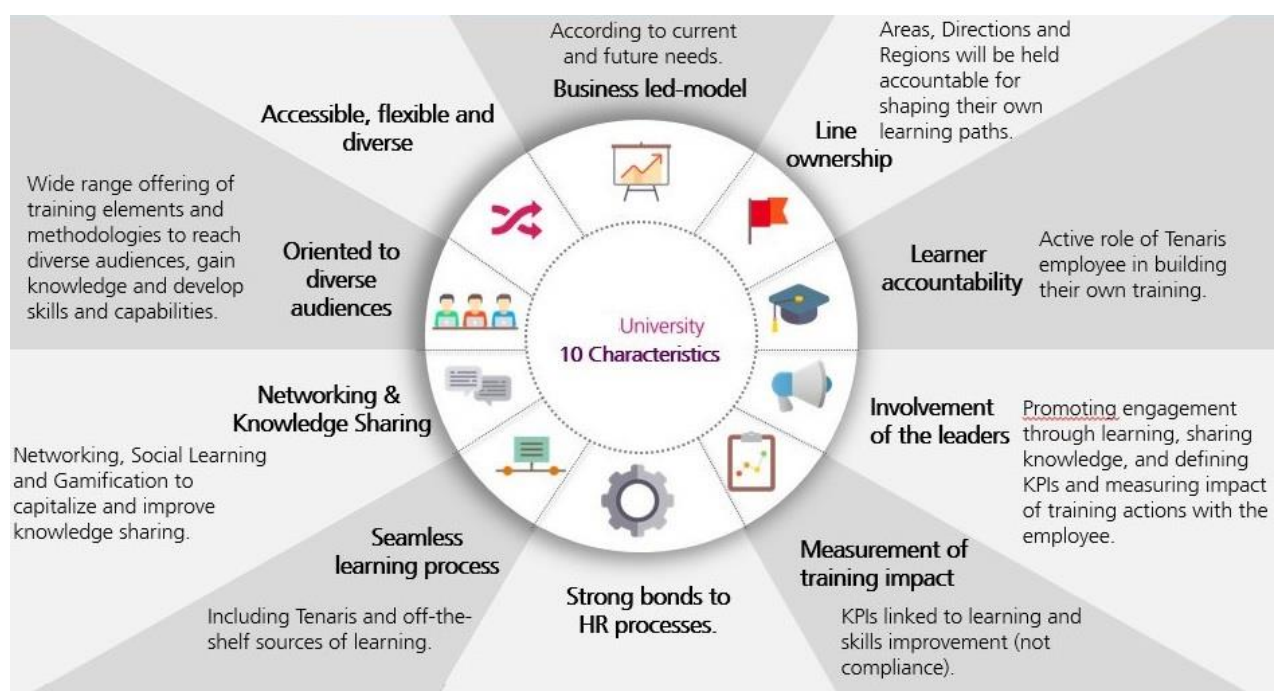

Figure 4.2 What education institutions should provide to students

Source: author's adaptation of www.tenaris.com

20 DE GRUYTER OPEN
Studia Universitatis "Vasile Goldis" Arad. Economics Series Vol 27 Issue 4/2017 ISSN: 1584-2339; (online) ISSN: 2285 - 3065

Web: publicatii.uvvg.ro/index.php/studiaeconomia.Pages $12-25$ 
As depicted by Figure 4.3, the future predicts a major turning point for the people with minimal skills and education. Turning work that requires minimal skills into a mechanical process (within 20 years) leads to the disappearance of the profession. The $70 \%$ of people with only minimal skills will be replaced by performing machines, thus the demand for people with medium and higher education and skills will increase in the same rate as the decrease in profession areas.

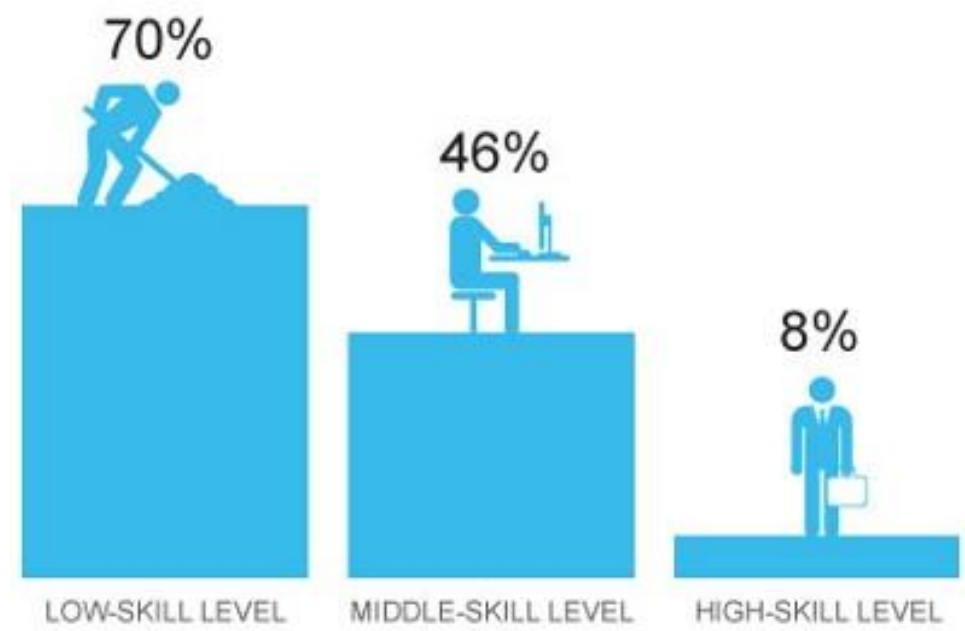

Figure 4.3 Required competencies level in the future Source: USA Today

In book "The future of the professions" (2015), the authors say that: the professions in their current form will no longer be the best answer to the actual needs, because we progress into a technology-based Internet society. We, as a society, are constantly changing, evolving, so our jobs are changing, so also the skills that we have if we have a certain profession. For example, online courses are the most modern and sought-after way to acquire skills by young people. (Susskind, Susskind, 2015)

Therefore, young people, and not only them, need to adapt quickly to the changes that relate to the skills required in a particular job, if they want to have a job in the future. On the other hand, employers are very attentive to the skills and know-how of a potential employee, because it also counts on the value that the young man will give to his company.

DE GRUYTER OPEN
Studia Universitatis "Vasile Goldis" Arad. Economics Series Vol 27 Issue 4/2017 ISSN: 1584-2339; (online) ISSN: 2285 - 3065 
Pribac L., Ardelean D., Dudas L., Haiduc C., Anghelina A. (2017)

Aspects of youth competencies in the 21st century in the European Union

Studies reveal (Figure 4.4) that the recruitment process changed drastically in the past years, namely that nowadays the employers look around 5 to 7 seconds on a candidate $\mathrm{CV}$, pay more attention to details (grammatical mistakes, or the candidate email address) and more important the candidate public profile available on social websites in order to obtain an extended characterisation of that candidate.

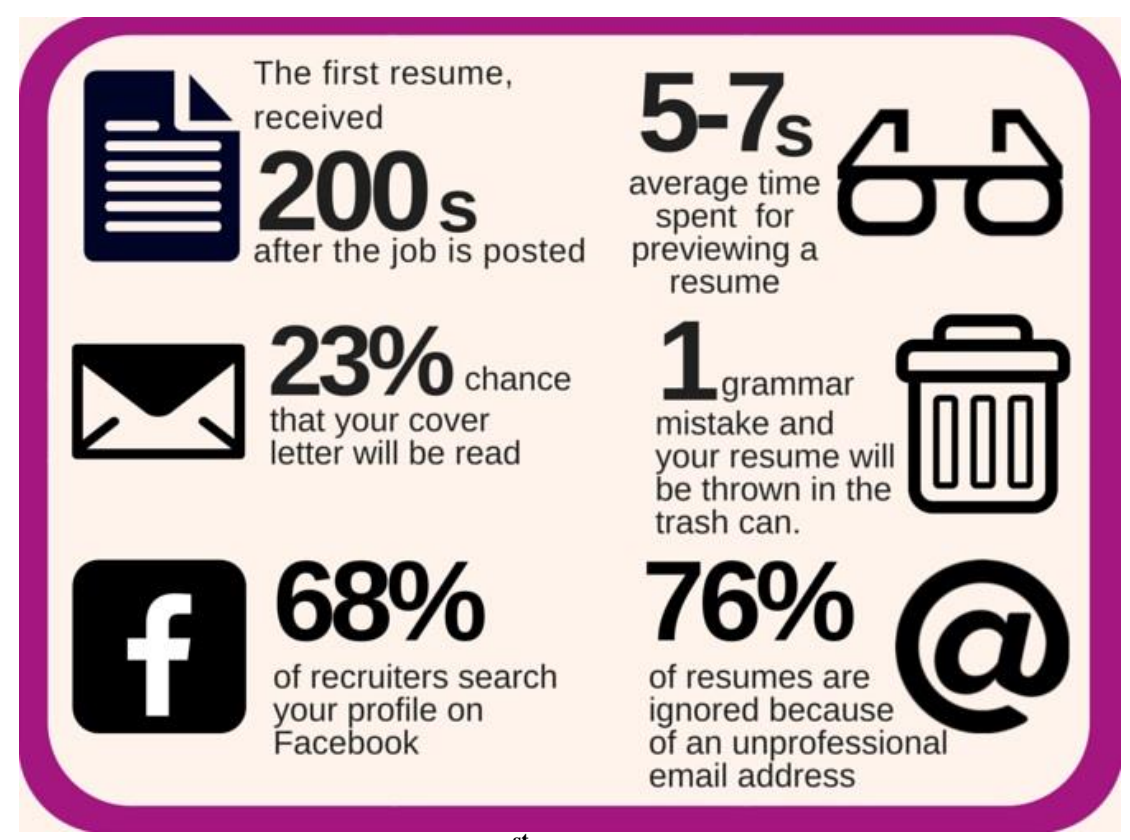

Figure 4.4 $21^{\text {st }}$ Century employers

Source: www.smartree.com

Present and future imply that: you need to be careful about the details, you have to have a complex CV and you have to be ready to accept the changes that take place in the field in which you work.

\section{Conclusion}

The recent financial crisis that broke out in 2008 and affected economies worldwide has generated stagnation in economic growth in most countries and, on the other hand, a high number of unemployed. Thus the young population has it difficult nowadays to find a good job. Moreover, the employers' requirements have change to a large extent in the $21^{\text {st }}$ Century all around the world. Maybe an explanation can be considerate the globalization process. To be more precise, the 
simple presence of multinational companies in different countries, in time changes the requirements of local employers. This is happening due to the fact that multinationals follow the same procedure of recruitment process in all countries as the one practice in the home country.

The main result of this study can be summarizing as follows. First, we observed that young people unemployment in Romania is almost at half of the situation in Spain or Greece. Second, the employers required competencies changed over the last years, and can be divided in three main groups: fundamental, skills that are acquired during school years but which relate to communication, social skills. Furthermore, we observed that the required skills of European employers are encountered also at the Romanian employers in recent years. Thirdly, we detected a discrepancy between the job offer on the Romanian market and the domains where people are looking for a job. To this end we encourage cooperation, between the government, universities and the business area. To be more precise, when the government establish the list of actions in order to resolve the unemployment problem a dialog with the business environment and universities should take place in order to provide candidates that fulfill the employers' requirements. Fourthly, we reveal some future directions on this topic. It is important to mention that the educational system need to keep up to the changes in the society in order to produce hirable graduates nowadays. Furthermore, the trend is to replace the jobs that require minimal skills by machines, thus generating an increase in the demand for medium and higher skilled people in the future. Another important observation is that nowadays employers pay less attention to a candidate CV and more attention to his personality (thorough details like errors on $\mathrm{CVs}$ or the candidate profile on social websites).

This topic is very ample and necessitates further studies in order to encounter the perfect solution for the discrepancies in the job offer and demand in the European Union, but also in Romania. Further research of the authors will try to identify the specific characteristics of the Romanian market, in order to improve the unemployment situation of young people.

\section{References}

1. Albu, L., Caraiani, P, Iordan M. (2012) Perspectivele pieţei muncii din România în contextul Strategiei Europa 2020, Editura Economică, București

2. Boboc,C, Titan, E, Tudose, D (2011) „Piața muncii din România - persoane vulnerabile și vulnerabilități, Romanian” Statistical Review Nr. 5/2011

3. Caliendo, M, Künn, S, Schmidl, R (2011) „Fighting Youth Unemployment: The Effects of Active Labor Market Policies" IZA DP No. 6222

Studia Universitatis "Vasile Goldis" Arad. Economics Series Vol 27 Issue 4/2017 ISSN: 1584-2339; (online) ISSN: 2285 - 3065

Web: publicatii.uvvg.ro/index.php/studiaeconomia.Pages $12-25$ 
Pribac L., Ardelean D., Dudas L., Haiduc C., Anghelina A. (2017)

Aspects of youth competencies in the 21 st century in the European Union

4. Neagu O., Neagu M. (2016) „Regional specialisation and economic concentration in Romania", Studia Universitatis "Vasile Goldiș" Arad - Economics Series, Vol. 26 nr. $3 / 2016$

5. Parrot. J, Treschan, L (2013) „The Increasing Challenger Faced by Young Adults”, Barriers to Entry, JobsFirstNYC/ 2013

6. Susskind R., Succkind D. (2015) „The future of the professions”, Oxford University Press

7. Wilson T (2013) „Youth Unemployment: Review of Training for Young People with Low Qualifications" Centre for Economic and Social Inclusion Research, Paper number 101, www.bis.gov.uk

8. ***Eurostat - http://appsso.eurostat.ec.europa.eu/nui/setupDownloads.do

9. ***www.mckinsey.com Report 2015: Education to employment: Getting Europe's youth into work

10. ***IZA Report Research Report No. 53 (2013) Combining the Entry of Young People inthe Labour Market with the Retentionof Older Workers

11. ***www.myjob.ro

12. $* * * w w w . e j o b s . r o$

13. $* * * w w w . b e s t j o b s . r o$

14. ***Career planning https://targetjobs.co.uk/careers-advice/career-planning/273051the-top-10-skills-thatll-get-you-a-job-when-you-graduate

15. ***Career advice https://www.prospects.ac.uk/careers-advice/applying-for-jobs/whatskills-do-employers-want

16. $* * * w w w . c e d e f o p . e u r o p a . e u$

17. ***https://www.kent.ac.uk/careers/sk/top-ten-skills.htm

18. ***https://www.skillsyouneed.com/general/employability-skills.html

19. ***http://www.smartree.com/en/infographics/

20. ***http://www3.weforum.org/docs/GAC/2014/WEF_GAC_Employment_MatchingSk illsLabourMarket_Report_2014.pdf

21. ***http://www.immagic.com/eLibrary/ARCHIVES/GENERAL/JOURNALS/H08120 0A.pdf

22. ***http://www.skillsforemployment.org/KSP/en/KnowledgeProducts/Casestudies/

23. ***http://www.revistadestatistica.ro/wpcontent/uploads/2014/10/RRS_03_2014_A5.pdf

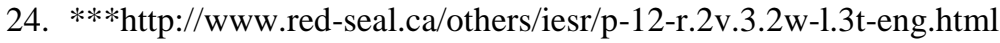

25. ***http://www.oecd.org/cfe/leed/localskillsstrategies.htm

26. $* * *$ http://blog.blomming.com/

27. ***http://www3.weforum.org/docs/GAC/2014/WEF_GAC_Employment_MatchingSk illsLabourMarket_Report_2014.pdf

28. ***https://tjobs.eu/candidate/edit/cv/education

29. ***Quality Youth Work - European Commission, 2015 
Pribac L., Ardelean D., Dudaș L., Haiduc C., Anghelina A. (2017)

Aspects of youth competencies in the 21 st century in the European Union

Vacant Jobs in Romania

Annex

Source: Project "O carieră pentru viața ta! Oportunități de carieră prin orientare și consiliere profesională““- SOPHRD 161/2.1/G/132792

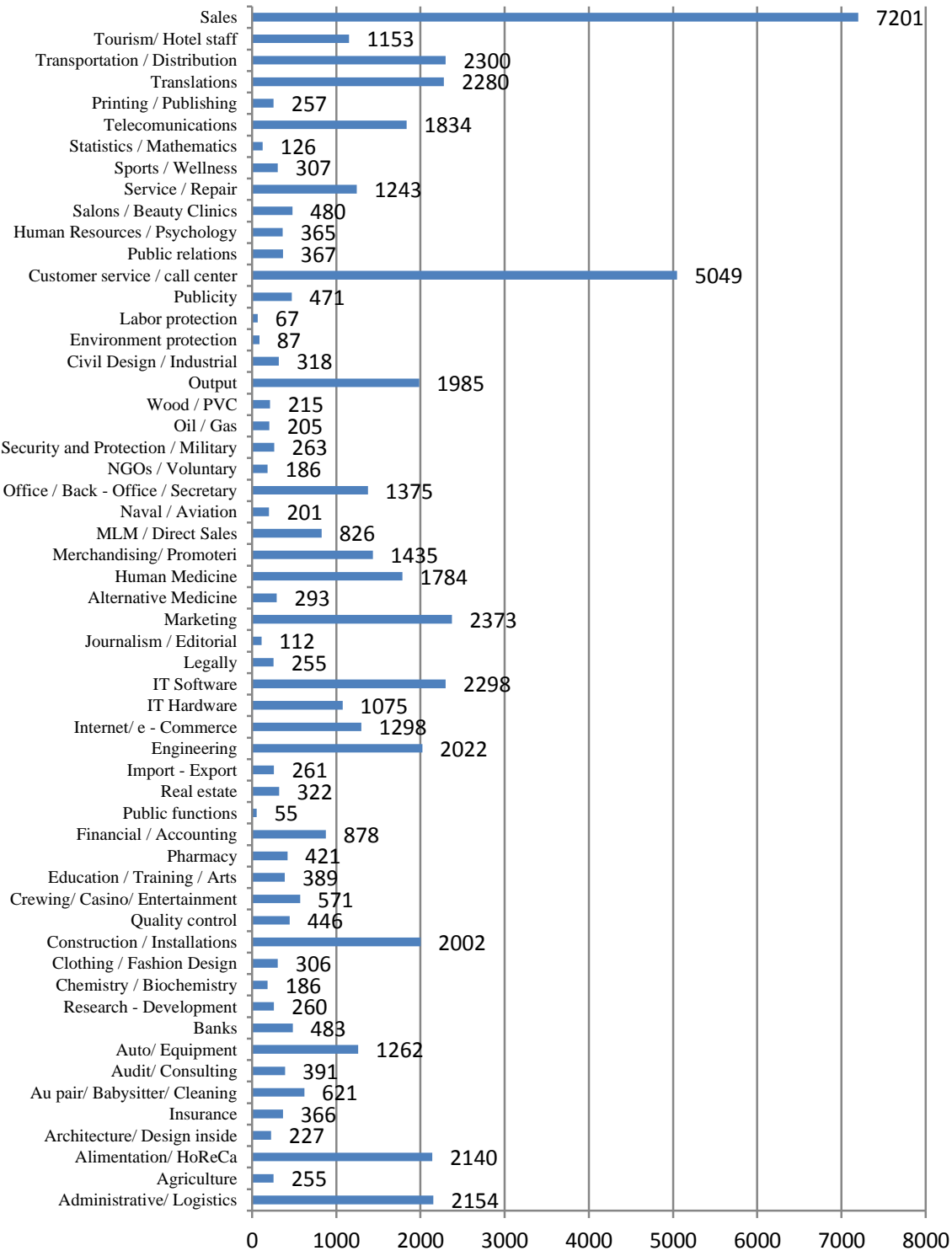

DE GRUYTER OPEN
Studia Universitatis "Vasile Goldis" Arad. Economics Series Vol 27 Issue 4/2017 ISSN: 1584-2339; (online) ISSN: 2285 - 3065 